\title{
Fistula Sample Numbers Required to Deter- mine Cattle Diets on Forest and Grassland
} Ranges

\author{
J.L. HOLECHEK AND M. VAVRA
}

\begin{abstract}
The variation among esophageal fistulated (EF) cattle in diet nutritive content and botanical composition selection was evaluated on forest and grassland range in the Blue Mountains of eastern Oregon during the summer of 1976. Botanical composition of diet samples was determined with microhistological analysis. Nutritive value was evaluated by analyses for crude protein, acid detergent fiber, permanganate lignin, and in vitro organic matter digestibility. Four collections were made from $4 \mathrm{EF}$ heifers during each of 428-day periods on each vegetation type. Collections were alternated between morning and afternoon on each vegetation type. EF cattle selected diets of different $(P<.05)$ botanical composition and nutritive quality in the early morning compared with the late afternoon. They grazed open grassland areas in the morning and shaded areas in the afternoon. Several more EF cattle and collections were required to determine diet botanical composition than nutritive quality on both the forest and grassland. A minimum of 4 EF cattle and 4 collections were needed to adequately sample diet nutritive characteristics on the grassland and forest pastures. The data indicated collections should be rotated between morning and afternoon on ranges supporting a mosaic of grassland and forest plant communities.
\end{abstract}

Studies relating cattle diet nutritive content and botanical composition have been reported for most grassland range types in the United States (Theurer et al. 1976), but data on forest ranges are still lacking. With the expected increased demand on forest ranges in the West for 180 million more animal-unit-months of grazing per year by the year 2000 (Forest and Range Task Force, 1972), research concerning livestock production on forest lands should be intensified. Guidelines for data accumulation need to be developed. In recent years, most of the research evaluating livestock diet botanical composition on rangeland has been conducted with esophageal fistulated animals. However, the number of samples required to estimate dietary components has not been established on all ranges types. Van Dyne and Heady (1965a) reported that 3 to 4 cattle or sheep would sample most dietary chemical constituents with $90 \%$ confidence within $10 \%$ of the mean on California annual grassland range. Other studies on different grassland ranges have shown similar results (Obioha et al. 1970, Wallace and Van Dyne 1970, Rosiere et al. 1975a). More animals are required to evaluate diet botanical composition than nutritive content (Van Dyne and Heady $1965 a, b)$. This study determined the number of esophageal fistula samples required to evaluate cattle diet botanical composi-

\footnotetext{
Authors at the time of the research were graduate research assistant, and professor of range nutrition, respectively, Oregon State University, Eastern Oregon Agricultural Research Center, Union, 97883. J.L. Holechek is currently associate professor of range science, Department of Animal and Range Science, New Mexico State University, Las Cruces $\mathbf{8 8 0 0 3 .}$

This report is Oregon State Agr. Exp. Sta. Tech. Paper 5919. This research was jointly funded by the Eastern Oregon Agr. Res. Center, Oregon State Univ. and the Forest Service, USDA, and was part of the Pacific Northwest Forest and Range Exp. Sta. Project 1701, "The Influence of Cattle Grazing Methods and Big Game on Riparian Vegetation, Aquatic Habitat and Fish Populations."

Manuscript received June 29, 1981.
}

tion on forest and adjacent grassland range in northeastern Oregon in 1976. The influence of collection time on results was also evaluated.

\section{Methods}

Grazing was conducted on one forest and one grassland pasture at the Starky Experimental Range and Forest in northeastern Oregon in 1976. Pastures were delineated so that approximately the same amount of forage was available on each. Details of experimental pastures and climate were reported by Holechek (1980), Holechek et al. (1981), and Holechek et al. (1982a,b). Both the forest and grassland pastures were stocked with 26 yearling cattle. Four of the 26 cattle on each pasture were esophageal fistulated. The 8 (EF) animals (4 on each pasture) grazed continuously on each pasture throughout the grazing season, which was divided into 4 periods: late spring (June 20 to July 18), early summer (July 19 to Aug. 15), late summer (Aug. 16 to Sept. 12), and fall (Sept. 13 to Oct. 10). Four sample collections from each EF heifer were taken on each pasture during each period.

The sampling scheme involved taking one early morning and one late afternoon collection from each pasture within the same week on a biweekly basis throughout the grazing season. Procedures for morning collections involved penning animals in late afternoon and initiation of collection the following morning at 0730 hours. For afternoon collections animals were penned at mid-afternoon and collections were initiated at 1630 hours. Penned animals were provided with water. The collection procedure involved slowly moving the EF heifers through each pasture until they started to graze and then allowing them to graze freely until at least a $1-\mathrm{kg}$ grazed forage sample was acquired. Areas selected for collections were based on recent observation of grazing activity. A total of 4 samples were collected from each heifer on each pasture for each period.

Fistula samples were collected with screened bottom bags, frozen immediately after collection, later dried in a forced air oven at $40^{\circ} \mathrm{C}$ for 7 days and then ground through a $1-\mathrm{mm}$ screen. Crude protein was determined by AOAC (1975) methods. Acid detergent fiber and permanganate lignin were determined by the techniques of Van Soest and Wine (1968) using the micro procedure of Holechek and Vavra (1983). In vitro digestibility was determined by the technique of Tilley and Terry (1963) as modified by Vavra et al. (1973). All diet quality data were converted to an organic matter basis for statistical evaluation. Data on trends in diet quality and livestock performance on the forest and grassland in 1976, 1977, and 1978 are given in Holechek et al. (1981). Diet botanical composition data for the same 3 years are given in Holechek et al. (1982a) for the grassland and Holechek et al. (1982b) for the forest.

The microhistological technique of Sparks and Malechek (1968) was used in botanical analysis of diet samples. Twenty microscope fields were examined at $100 \times$ on each of 3 slides for each diet sample. 
Differences in botanical and chemical composition of livestock diets between morning and afternoon within the forest and grassland pastures were evaluated using analysis of variance. The number of diet samples required for a given precision level in each vegetation type for each period was calculated using the formula of Stein (1945):

$$
N=\frac{\left(t^{2}\right)\left(s^{2}\right)}{d^{2}}
$$

In this formula $N$ is the computed sample size, $t$ is the tabulated value for the desired confidence level and the degrees of freedom of the initial sample, $d$ is the half-width of the desired confidence interval, and $s^{2}$ is the variance of the initial sample (Steel and Torrie 1960). Sums of squares associated with heifers and collections for each period were partitioned using a completely randomized analysis of variance. Heifer and collection variances were then calculated by the formula of Steel and Torrie (1960):

$$
S_{m}=-\frac{s^{2}}{n_{1} m}+\frac{s^{2}}{a}-
$$

In this formula $S_{\mathrm{m}}$ represents the minimum variance, $n_{1}$ represents the number of heifers (4), $m$ represents the number of collections (4), $s$ is the sum of squares for heifers, and $s_{w}$ is the sum of squares for collections. The minimum variance $\left(S_{\mathrm{m}}\right)$ was used as the variance $\left(s^{2}\right)$ in Stein's (1945) formula to estimate the total sample size; the variance for heifers $\left(s^{2} / n_{1}\right)$ was used to estimate the number of heifers required; and the variance for collections $\left(s_{w}^{2} / n_{1} m\right)$ was used to estimate the number of collections required. This procedure made it possible to determine the optimal number of individual cattle and collections needed for determinations of diet botanical composition and nutritive components on each vegetative type. Because of the small sample size (4 collections), collection variances were not further partitioned into variances associated with time of day.

\section{Results and Discussion}

Cattle diet botanical composition on the 2 vegetation types was different $(\boldsymbol{P}<.05)$ between early morning and late afternoon collections. Because diet species interactions between period and time of day were generally nonsignificant $(P>.05)$, data were pooled across periods (Table 1). During most of the grazing season, temperatures were $28^{\circ} \mathrm{C}$ or more by noon. Cattle on both vegetation types preferred to graze in shaded areas in the late afternoon probably to escape the heat. Cattle in the afternoon grazed more slowly and appeared to be less concerned with achieving fill compared with grazing in the early morning. In the morning open areas may have been preferred because they were warmer. Early morning temperatures were often near freezing and open areas were much warmer than forested areas due to more sunlight.

In this study, shrub species were relatively unavailable in the open grassland areas of both pastures, but were an important part of the understory in forested areas. About $20 \%$ of the grassland pasture supported a very open stand of ponderosa pine (Pinus ponderosa) with an understory of Idaho fescue (Festuca idahoensis) and common snowberry (Symphoricarpos albus). Cattle showed a strong preference for the interior or edges of these areas in almost all afternoon collections. In the morning they invariably chose to graze open grassland areas dominated by bluebunch wheatgrass (Agropyron spicatum). Forest cattle almost always grazed the forest openings dominated by Idaho fescue and bluebunch wheatgrass in the morning, but in the afternoon they utilized the more heavily forested areas dominated by elk sedge (Carex geyeri) and common snowberry in the understory and douglas fir (Pseudotsuga menziesii) in the overstory.

It appears fistula collections for diet botanical composition determination with cattle should be rotated between morning and afternoon on ranges supporting a mosaic of forcst and grassland plant communities. Kirby and Stuth (1982) found that during the summer cattle in Texas preferred to graze in the shade of woody plants on post oak savannah range in Texas. Their study showed cattle consumed more forbs and shrubs during the afternoon than morning in this period. They concluded that research based on morning diet collections only might result in biased samples. Van Dyne and Heady (1965b) indicated that cattle grazed more selectively during the afternoon than mornings on California annual grassland range. Obioha et al. (1970) reported cattle selected more grass than forbs in the morning, but reversed this selection in the afternoon on grassland range in Nebraska.

The number of diet samples needed for botanical composition determination was much greater than for nutritive value (Tables 2 and 4). Others have reported similar findings using fistulated animals (Van Dyne and Heady 1965b, Galt et al. 1969, Harniss et al. 1975). High variability existed between both cattle and collections for minor species in the diet and only 60 microscope fields were examined per diet sample. Holechek and Vavra (1981) reported that this number of slides gave adequate precision $(90 \%$ confidence, $10 \%$ of the mean) for species comprising $30 \%$ or more of the diet but was inadequate for species present in lesser amounts. Harniss et al. (1975) reported that a large number of diet samples was needed for botanical analysis of sheep diets in eastern Idaho to

Table 1. Mean percentage weight of important species in cattle diets pooled across the grazing season on the forest and grassland vegetation types in the

\begin{tabular}{|c|c|c|c|c|}
\hline \multirow[b]{3}{*}{ Species } & \multicolumn{4}{|c|}{ Vegetation type and collcction time } \\
\hline & \multicolumn{2}{|c|}{ Forest } & \multicolumn{2}{|c|}{ Grassland } \\
\hline & Morning & Evening & Morning & Evening \\
\hline $\begin{array}{l}\text { Idaho fescue (Festuca idahoensis) } \\
\text { Bluebunch wheatgrass (Agropyron spicatum) } \\
\text { Elk sedge (Carex geyeri) } \\
\text { Sandberg bluegrass (Poa sandbergii) } \\
\text { Miscellaneous grasses } \\
\quad \text { Total grasses }\end{array}$ & $\begin{array}{c}26^{\mathrm{a}} \\
13^{\mathrm{a}} \\
3^{\mathrm{a}} \\
1 \\
28^{\mathrm{a}} \\
71^{\mathrm{a}}\end{array}$ & $\begin{array}{c}16^{\mathrm{b}} \\
5^{\mathrm{b}} \\
17^{\mathrm{b}} \\
0 \\
18^{\mathrm{b}} \\
56^{\mathrm{b}}\end{array}$ & $\begin{array}{l}25^{\mathrm{a}} \\
34^{\mathrm{a}} \\
\mathrm{t} \\
3 \\
24^{\mathrm{a}} \\
86^{\mathrm{a}}\end{array}$ & $\begin{array}{c}37^{\mathrm{b}} \\
24^{\mathrm{b}} \\
1 \\
2 \\
12^{\mathrm{b}} \\
76^{\mathrm{b}}\end{array}$ \\
\hline $\begin{array}{l}\text { Western yarrow (Achillea millefolium) } \\
\text { Miscellaneous forbs } \\
\text { Total forbs }\end{array}$ & $\begin{array}{r}3 \\
14 \\
17\end{array}$ & $\begin{array}{r}1 \\
18 \\
19\end{array}$ & $\begin{array}{r}4 \\
7 \\
11\end{array}$ & $\begin{array}{r}2 \\
11 \\
13\end{array}$ \\
\hline $\begin{array}{l}\text { Common snowberry (Symphoricarpos albus) } \\
\text { Miscellaneous shrubs } \\
\text { Total shrubs }\end{array}$ & $\begin{array}{c}5 \\
7 \\
12\end{array}$ & $\begin{array}{c}18^{b} \\
7 \\
25^{b}\end{array}$ & $\begin{array}{l}2^{a} \\
1 \\
3^{a}\end{array}$ & $\begin{array}{c}9^{\mathrm{b}} \\
2 \\
11^{\mathrm{b}}\end{array}$ \\
\hline
\end{tabular}
morning and evening.

\footnotetext{
abeans for each row are different $(P<.05)$.
}

$t=$ trace. 
Tabie 2. The number of cattle diet samples required to determine botanical composition on forest and grassland range.

\begin{tabular}{|c|c|c|c|c|c|c|c|c|c|c|}
\hline \multirow[b]{3}{*}{ Forage species } & \multicolumn{10}{|c|}{ Vegetation type and period } \\
\hline & \multicolumn{5}{|c|}{ Forest } & \multicolumn{5}{|c|}{ Grassland } \\
\hline & $\begin{array}{c}\text { Late } \\
\text { summer }\end{array}$ & $\begin{array}{c}\text { Early } \\
\text { spring }\end{array}$ & $\begin{array}{c}\text { Late } \\
\text { summer }\end{array}$ & Fall & $\bar{X}$ & $\begin{array}{l}\text { Late } \\
\text { spring }\end{array}$ & $\begin{array}{l}\text { Early } \\
\text { summer }\end{array}$ & $\begin{array}{l}\text { Late } \\
\text { summer }\end{array}$ & Fall & $\overline{\boldsymbol{X}}$ \\
\hline ldaho fescue (Festuca idahoensis) & 227 & 105 & 58 & 145 & 134 & 164 & 26 & 30 & 31 & 63 \\
\hline Bluebunch wheatgrass (Agropyron spicatum) & 15 & 221 & 281 & 576 & 273 & 65 & 29 & 39 & 41 & 44 \\
\hline Sandberg bluegrass (Poa sandbergii) & 894 & 700 & 998 & 1167 & 940 & 171 & 336 & 748 & 300 & 389 \\
\hline Total grasses & 13 & 28 & 53 & 19 & 28 & 16 & 8 & 6 & 7 & 9 \\
\hline Western yarrow (Achillea millefolium) & 467 & 480 & 221 & 106 & 319 & 257 & 193 & 285 & 314 & 262 \\
\hline Total forbs & 76 & 462 & 97 & 135 & 192 & 28 & 92 & 116 & 127 & 91 \\
\hline Common snowberry (Symphoricarpos albus) & 90 & 141 & 342 & 197 & 193 & 294 & 79 & 313 & 584 & 318 \\
\hline Total shrubs & 143 & 134 & 149 & 68 & 124 & 104 & 26 & 50 & 73 & 83 \\
\hline \multicolumn{11}{|c|}{ Number of animals } \\
\hline Total grasses & 4 & 6 & 9 & 5 & 6 & 4 & 2 & 2 & 2 & 2 \\
\hline Total forbs & 9 & 24 & 12 & 13 & 15 & 7 & 10 & 13 & 13 & 10 \\
\hline Total shrubs & 11 & 13 & 14 & 10 & 12 & 14 & 8 & 8 & 7 & 9 \\
\hline \multicolumn{11}{|c|}{ Number of collections } \\
\hline Total grasses & 3 & 5 & 6 & 4 & 4 & 4 & 4 & 3 & 4 & 4 \\
\hline Total forbs & 8 & 20 & 11 & 7 & 13 & 4 & 9 & 9 & 10 & 9 \\
\hline Total shrubs & 13 & 10 & 11 & 7 & 10 & 7 & 3 & 6 & 10 & 9 \\
\hline
\end{tabular}

achieve adequate precision ( $90 \%$ confidence, $10 \%$ of the mean) for minor botanical constituents of the diet when microhistological analysis was used. Van Dyne and Heady (1965a) reported that as many as 9 cattle would be required to sample forage classes on California annual grassland range. Galt et al. (1969) reported that 6 steers would adequately estimate the predominate grass species in the diet on semidesert grassland range in Arizona. Based on data presented herein, we believe that at least 5 cattle and 6 collections are needed to adequately ( $90 \%$ confidence, $10 \%$ of the mean) sample forage classes, but many more animals and collections may be needed for major dietary species. It may be impractical to sample species comprising less than $30 \%$ of the diet with adequate precision ( $90 \%$ confidence, $10 \%$ of the mean). Sampling limitations should be recognized by researchers when they interpret diet botanical composition data from fistulated animals. In our study too few cattle and collections may have been used for reliable estimates of variances associated with diet botanical composition.

Cattle diets on both vegetation types were consistently higher in crude protein (CP) in the afternoon compared to the morning (Table 3). The high CP content of afternoon compared to morning diets is attributed to afternoon preference by cattle for forested areas where forage was more succulent and less advanced phenologically compared to grassland areas. Cattle also appeared to graze more slowly and selectively in the afternoon. Insects were of minor importance on both the forest and grassland pastures and did not appear to influence where the cattle grazed. Van Dyne et al. (1964) on southwestern Montana bunchgrass range and Bedell (1979) on grass-clover pastures in Oregon reported little difference in $C P$ content between morning and afternoon cattle diets. In contrast, Van Dyne and Heady (1965a) on California annual grassland range and Kirby and Stuth (1982) on Texas post oak range reported the CP content of cattle diets was higher in the afternoon

Table 3. Nutritive quality of cattle diets on the forest and grassland in the morning and evening.

\begin{tabular}{lccccc}
\hline \hline & \multicolumn{4}{c}{ Vegetation type } \\
\cline { 2 - 3 } \cline { 5 - 6 } Nutritive measurement & \multicolumn{2}{c}{ Forest } & & \multicolumn{2}{c}{ Grassland } \\
\cline { 2 - 3 } \cline { 5 - 6 } & Morning & Evening & & Morning & Evening \\
\hline Crude protein \% & $10.8^{\mathrm{a}}$ & $13.1^{\mathrm{b}}$ & & $11.6^{\mathrm{a}}$ & $13.1^{\mathrm{b}}$ \\
Acid detergent fiber \% & $58.2^{\mathrm{a}}$ & $54.7^{\mathrm{b}}$ & & 56.9 & 57.7 \\
Permanganate lignin \% & $14.7^{\mathrm{a}}$ & $18.0^{\mathrm{b}}$ & & 13.7 & 15.0 \\
In vitro digestibility \% & 57.2 & 57.8 & & 58.6 & 57.5 \\
\hline
\end{tabular}

a,beans for each row are different $(\mathbb{P}<.05)$. than morning. Our study and that of Kirby and Stuth (1982) are consistent in showing that in vitro organic matter digestibility diurnal differences in cattle diets are not significant $(P>.05)$. Our results suggest that collections with fistulated cattle for determination of diet quality should be rotated between morning and afternoon on ranges supporting a mosaic of forest and grassland communities.

We believe that at least 4 cattle and 4 collections are needed to adequately sample nutritive quality on the ranges studied (Table 4). Van Dyne and Heady (1965a) reported that 2 steers would adequately ( $90 \%$ confidence, $10 \%$ of the mean) sample most diet nutritive parameters on California annual grassland range. Rosiere et al. (1975) reported that 4 to 6 steers were needed $(90 \%$ confidence, $10 \%$ of the mean) to evaluate diet nutritive content of semi-desert range in southcentral New Mexico. Data reported by Wallace and Van Dyne (1970) suggested that 3 to 4 steers were needed to evaluate diet nutritive quality on sandhill range in Colorado ( $90 \%$ confidence, $10 \%$ of the mean).

\section{Conclusions}

Results of Van Dyne and Heady (1965a,b), Kirby and Stuth (1982), and the present study show diurnal differences can occur in cattle diet botanical composition and nutritive quality. It is important to recognize that different range ecosystems have different climatic and vegetational characteristics which change throughout the year. Therefore researchers must give careful consideration to selection of the best sampling time or times for their situation. If evaluation of relative differences in diets between pastures is the main concern, consistency in sampling time or times is of critical importance.

Length of collection time appears to have considerable influence on variability between fistulated animals based on qualitative observations made by the authors. Cattle in our study were allowed a grazing period of at least $\mathbf{3 0}$ minutes and usually much more during each collection which resulted in an accumulation of a large volume of forage by each animal. Also this gave individual animals more opportunity to graze different areas within a pasture which minimized the effect of pasture plant community heterogeneity on results.

We believe the same fistulated animals should be kept on the same study pasture if at all possible when the study objective is to compare diet differences within or between years. This will avoid confounding grazing habits of individual animals with dietary differences caused by seasonal advance or climatic differences between years. In addition fistula samples will better represent the 
Table 4. The number of cattle diet samples required to determine nutritive quality on forest and grassland range with $90 \%$ confidence the estimate is within $10 \%$ of the mean.

\begin{tabular}{|c|c|c|c|c|c|c|c|c|c|c|}
\hline \multirow[b]{3}{*}{ Nutritive measurement } & \multicolumn{10}{|c|}{ Vegetation type and period } \\
\hline & \multicolumn{5}{|c|}{ Forest } & \multicolumn{5}{|c|}{ Grassland } \\
\hline & $\begin{array}{l}\text { Late } \\
\text { spring }\end{array}$ & $\begin{array}{c}\text { Early } \\
\text { summer }\end{array}$ & $\begin{array}{c}\text { Late } \\
\text { summer }\end{array}$ & Fall & $\bar{x}$ & $\begin{array}{c}\text { Late } \\
\text { spring }\end{array}$ & $\begin{array}{c}\text { Early } \\
\text { summer }\end{array}$ & $\begin{array}{c}\text { Late } \\
\text { summer }\end{array}$ & Fall & $\bar{X}$ \\
\hline Crude protein $\%$ & 25 & 20 & 17 & 14 & 19 & 6 & 15 & 33 & 11 & 15 \\
\hline Acid detergent fiber $\%$ & 20 & 11 & 13 & 17 & 15 & 5 & 13 & 16 & 10 & 11 \\
\hline Permanganate lignin $\%$ & 8 & 13 & 22 & 32 & 19 & 6 & 7 & 13 & 7 & 8 \\
\hline In vitro digestibility $\%$ & 17 & 9 & 13 & 24 & 16 & 6 & 10 & 8 & 6 & 7 \\
\hline \multicolumn{11}{|c|}{ Number of animals } \\
\hline Crude protein $\%$ & 5 & 4 & 4 & 4 & 4 & 2 & 3 & 6 & 3 & 4 \\
\hline Acid detergent fiber $\%$ & 4 & 3 & 4 & 4 & 4 & 3 & 3 & 3 & 4 & 3 \\
\hline Permanganate lignin $\%$ & 4 & 4 & 5 & 7 & 5 & 2 & 2 & 3 & 4 & 3 \\
\hline In vitro digestibility $\%$ & 4 & 2 & 4 & 6 & 4 & 2 & 3 & 3 & 2 & 3 \\
\hline \multicolumn{11}{|c|}{ Number of collections } \\
\hline Crude protein $\%$ & 5 & 5 & 4 & 4 & 5 & 3 & 5 & 6 & 4 & 4 \\
\hline Acid detergent fiber $\%$ & 5 & 4 & 3 & 4 & 4 & 2 & 4 & 5 & 3 & 4 \\
\hline Permanganate lignin $\%$ & 2 & 3 & 5 & 5 & 4 & 3 & 3 & 4 & 2 & 3 \\
\hline In vitro digestibility $\%$ & 4 & 4 & 3 & 4 & 4 & 3 & 3 & 3 & 3 & 3 \\
\hline
\end{tabular}

nutritive quality of the forage selected because the basal diet can significantly influence the chemical composition of the saliva (Mayland and Lesperance 1977). For comparing diets between pastures the use of the same animals on all experimental pastures appears to have many advantages if the same forage species are available on each pasture or if all the animals can be kept in a nonexperimental pasture having a botanical composition similar to that of the experimental pasture. The advantage of this sampling scheme is that the number of animals used in sampling can be greatly increased since only one group of animals is required. If 4 or fewer animals are used as sampling agents, results are not greatly confounded by forage preferences of individual animals on each pasture. The use of all animals to sample each pasture has the additional advantage of reducing labor inputs since fewer collections are required. The 2 primary problems with this scheme are that more personnel may be required per collection and that it may be difficult or impossible to sample pastures separated by physical barriers or large distances. If the same group of animals is used to sample each pasture, crossover analysis of variance procedures discussed by Cochran and Cox (1957) should be used.

When diet data are evaluated statistically, only animals pooled across collections should be used to obtain an estimate of experimental error. Collections provide an estimate of variation associated with each animal or sampling error and should be considered as subsamples. Steel and Torrie (1960) provide a comprehensive discussion of analysis of variance procedures when subsamples are involved.

\section{Literature Cited}

AOAC. 1975. Official Methods of Analysis, (12th ed.). Association of Official Analytical Chemists, Washington, D.C.

Bedell, T.E. 1971. Nutritive value of forage and diets of sheep and cattle from Oregon sub-clover grass mixtures. J. Range Manage. 24:125-133.

Cochran, W.G., and G.M. Cox. 1957. Experimental Designs, 2nd Ed. Wiley Publ. Co., New York.

Forest-Range Task Force. 1972. The nation's range resources-a forestrange environmental study. Forest Res. Rep. No. 19, USDA Forest Serv. Washington, DC.

Galt, H.D., B. Theurer, J.H. Ehrenreich, W.H. Hale, and S.C. Martin. 1969. Botanical composition of diet of steers grazing a desert grassland range. J. Range Manage. 22:14-19.

Harniss, R.O., D.A. Price, and D.C. Tomlin. 1975. Number of fistula samples needed for determination of sheep diet on sagebrush-grass range. J. Range Manage. 28:417-419.

Holechek, Jerry L. 1980. The effects of vegetation type and grazing system on the performance, diet and intake of yearling cattle. Ph.D. Thesis, Oregon State Univ., Corvallis.
Holechek, Jerry L., and M. Vavra. 1981. The effects of slide and frequency obscrvation numbers on the precision of microhistological analysis. $J$. Range Manage. 33:337-338.

Holechek, J.L., and M. Vavra. 1983. Comparison of micro- and macrodigestion methods for fiber analysis. J. Range Manage. 35:799-801.

Holechek, J.L., M. Vavra, and J. Skovlin. 1981. Diet quality and performance of cattle on forest and grassland range. J. Animal Sci. 52:291-299.

Holechek, J.L., M. Vavra, J. Skovlin, and W.C. Krueger. 1982a. Cattle diets of the Blue Mountains of Oregon, I. Grasslands. J. Range Manage. 35:109-113.

Holechek, J.L., M. Vavra, J. Skovlin, and W.C. Krueger. 1982b. Cattle diets in the Blue Mountains of Oregon, II. Forests. J. Range Manage. 35:239-243.

Kirby, D.R., and J.W. Stuth. 1982. Seasonal diurnal variation in composition of cow diets. J. Range Manage. 35:7-8.

Mayland, H.F., and A.L. Lesperance. 1977. Mineral composition of rumen fistula samples compared to diet. J. Range Manage. 30:388-390.

Obioha, F.C., D.C. Clanton, L.R. Rittenhouse, and C.J. Streeter. 1970. Sources of variation in chemical composition of forage ingested by esophageal fistulated sheep. J. Range Manage. 23:133-135.

Rosiere, R.E., J.D. Wallace, and R.F. Beck. 1975. Cattle diets on a semidesert grassland: nutritive value. J. Range Manage. 28:94-96.

Sparks, D.R., and J.C. Malechek. 1968. Estimating percentage dry weight in diets using a microscopic technique. J. Range Manage. 21:264-266.

Steel, R.G.D., and J.H. Torrie. 1960. Principles and procedures of statistics. McGraw-Hill Book Co., New York.

Stein, C. 1945. A two-sample test for a linear hypothesis whose power is independent of the variance. Ann Math. Stat. 16:243-258.

Tilley, J.M.A., and R.A. Terry. 1963. A two-story technique for the in vitro digestion of forage crops. J. Brit. Grassl. Soc. 18:104-111.

Theurer, C., Brent, A.L. Lesperance, and Joe D. Wallace. 1976. Botanical composition of the diet of livestock grazing native ranges. Arizona Univ. Agr. Exp. Sta. Bull. 233.

Van Dyne, G.M., O.O. Thomas, and J.L. Van Horn. 1964. Diets of cattle and sheep on winter range. Proc. West. Sec. Amer. Soc. Anim. Sci. 15:1-6.

Van Dyne, G.M., and H.F. Heady. 1965a. Dietary chemical composition of cattle and sheep grazing in common on a dry annual range. J. Range Manage. 18:78-86.

Van Dyne, G.M., and H.F. Heady. 1965b. Botanical composition of sheep and cattle diets on a mature annual range. Hilgardia 36:465-470.

Van Soest, P.J., and R.H. Wine. 1968. Determination of lignin and cellulose in acid detergent fiber with permanganate. J. Assoc. Official Agri. Chem. 51:780-787.

Vavra, M., R.W. Rice, and R.E. Bement. 1973. Chemical composition of the diet, intake and gain of yearling cattle on different grazing intensities. J. Anim. Sci. 36:411-414.

Wallace, J.D., and G.M. Van Dyne. 1970. Precision of indirect methods for estimating digestibility of forage consumed by grazing cattle. J. Range Manage. 23:424-430. 